\title{
Педагогічна діяльність Олександра Кониського
}

Дяченко О. В.

Дніпровський національний університет імені Олеся Гончара

Висвітлено педагогічну діяльність українського письменника, педагога, громадського діяча О. Кониського та проаналізовано його педагогічні погляди.

Ключові слова: Олександр Кониський; педагог; недільні школи; громадсько-освітні діячі; громади; педагогіка; національна освіта

Освещена педагогическая деятельность украинского писателя, педагога, общественного деятеля А. Конисского и проанализированы его педагогические взгляды.

Ключевые слова: Александр Конисский; педагог; воскресные школы; общественно-образовательные деятели; педагогика; национальное образование

The article illuminates the pedagogical activity of Ukrainian writer, social activist, pedagogue Olexandr Konyskiy. His pedagogical thoughts are analyzed. The main idea of pedagogy of O. Konyskiy was national education, which had to be based on the nature of a child, its individuality and national features, it had to guarantee a harmonic unity of personal development with a spiritual development of nation. O. Konyskiy's heritage takes a prominent place in the history of national pedagogy. He is an author of numerous original works from the history of education, history of culture, literary criticism, didactics, the development of education in Ukraine. The problems of education were the subject of his researcher's attention.

In his numerous writings the pedagogue poses questions of family and moral education; the reform of the content of women's education, which is based on teaching mother tongue; Higher education for women. The ideas of the teacher were reviewed and developed later in the writings of a new generation of Ukrainian intellectuals, including B. Grinchenko, M. Hrushevsky, C. Rusova, I. Chepiga, I. Yuschyshyn and others. The views of O. Konyskiy on the problems of the development of the national school have not lost their relevance and now require further study and creative use in the process of developing a modern national school and education.

Keywords: Olexandr Konyskiy; pedagogue; Sundayschools; social and educativeactivists communities; pedagogue; national education

Вагомим в історії української педагогічної науки є період другої половини XIX ст. - час активного культурно-освітнього руху та нового витка розвитку національної педагогічної думки.Тому в сучасній історії актуалізується питання звернення до джерел української педагогічної думки. Вагомого значення набуває формування «персоналістичного» напряму в наукових працях. Останніми роками активізувалися дослідження, у яких науково обгрунтована оцінка діяльності педагогічних персоналій, які працювали для розвитку національної педагогічної думки. У наш час відчувається брак дослід-

(C) О. В. Дяченко, 2018 
жень 3 таких проблем, як освітньо-педагогічна діяльність багатьох громадських діячів XIX ст. Тому аналіз праць і життєвого шляху педагогів, письменників, громадських діячів, які зробили вагомий внесок у розвиток української педагогіки і яких свого часу не було належно оцінено, залишається актуальним.

Серед педагогів другої половини XIX ст. виступає постать Олександра Кониського (1836-1900) - видатного українського громадського діяча, письменника, публіциста, організатора недільних шкіл, ученого-шевченкознавця. Педагогічна діяльність та літературна спадщина О. Кониського привертали увагу багатьох дослідників. До непересічної особистості педагога в кінці XIX - початку XX ст. зверталися О. Авдикович, О. Барвінський, М. Возняк, М. Грушевський, О. Грушевський, С. Єфремов, О. Огоновський, К. Студинський, I. Франко, Є. Чикаленко та інші.

За радянських часів постать Олександра Кониського була заборонена з ідеологічних міркувань. Досить змістовною з погляду джерельної бази є опублікована у 1930 р. праця М. Гніпа «Громадський рух 1860 рр.: Полтавська громада» [3]. Більше третини ії обсягу склала публікація жандармсько-слідчих матеріалів щодо діяльності полтавських громадських діячів та їхньої епістолярної спадщини. Тут автор охарактеризував діяльність полтавських громадівців, до яких належав і О. Кониський, на початку 60-х рр. XIX ст., показав їх перші кроки щодо відкриття українських шкіл, проблеми та матеріальний стан, висвітлив відносини з іншими українськими громадами та народолюбцями (М. Костомаровим, П. Кулішем, С. Носом, М. Глібовим та ін.) [3]. Усе ж М. Гніп, на нашу думку, не зробив спроби різнобічно проаналізувати подані ним джерела, а лише констатував зафіксовані окремі факти. Також автор зазначеної праці ретельно не проаналізував педагогічну діяльність діячів Полтавської громади.

3 90-х pp. XX ст. ця тематика знайшла певне наукове висвітлення у ба-гатьох працях, серед яких для вивчення зазначеної теми мають для нас науковий інтерес роботи С. Світленка, Н. Побірченко, А. Кудрицького, Г. Бєлан, О. Мисюри та ін. До джерел, що стосуються педагогічної, громадсько-освітньої діяльності О. Кониського XIX ст., належать листування М. Костомарова з О. Кониським, листи Л. Глібова й С. Носа до О. Кониського, підготовлені до друку М. Возняком, що відкрило нові сторінки діяльності педагога, ознайомило з його поглядами на проблему освіти народу, продемонструвало стосунки із сучасниками. Іншим видом джерел є твори О. Кониського, які друкувалися на сторінках періодичних видань другої 
половини XIX ст., зокрема таких як «Основа», «Правда», «Записки Наукового товариства імені Шевченка», «Киевская Старина».

На межі 50-60-х pp. ХІХ ст., напередодні селянської реформи 1861 р., в Україні з новою силою завирувало національне громадсько-політичне життя. Українська національно-свідома інтелігенція, розуміючи, що українське суспільство у своїй переважній масі залишалося байдужим до власної освіти. Тому громадські діячі вбачали шлях розвитку українства у розвитку національної освіти. Таким чином, почали створювати недільні школи. Ці школи призначалися для ремісничої молоді, міщан і робітників. Навчання проводилося в неділю - вихідний день.

У 60-х pp. XIX ст. О. Кониський став активним громадським діячем, членом Полтавської громади, діяльність якої мала національно-культурницьке спрямування. У Полтаві він зійшовся з демократично налаштованими людьми, активними учасниками українського національного руху, зокрема з Д. Пильчиковим, педагогом, громадським діячем. Спілкування $з$ ним зміцнило переконання О. Кониського про необхідність перебудови суспільного життя, ліквідацію станової та правової нерівності. Тому свої зусилля він спрямовув на культурно-просвітницьку роботу. Разом із Д. Пильчиковим, В. Лободою, В. Куликом та іншими О. Кониський брав активну участь у заснуванні недільних шкіл, в організації навчального процесу у вечірній школі для молоді, суботніх школах для єврейських дітей. В усіх цих закладах Олександр Якович працював учителем історії, часто поєднуючи практичну педагогічну роботу з виконанням обов'язків адміністратора, бібліотекаря, секретаря педагогічної ради. Педагог, як і інші члени полтавської Громади, брав безпосередню участь у народних публічних лекціях, літературно-музичних вечорах, сприяв роботі народного театру.

Педагог глибоко вірив у можливість піднесення культурного рівня широких народних мас засобами освіти та українського шкільництва на національних засадах. Як зазначає П. Рогова, на початку 60-х рр. ХІХ ст. вітчизняні вчені, історики, педагоги «порушували питання щодо... поглиблення змісту освіти та необхідності відкриття бібліотек, відзначаючи їх важливість як осередків забезпечення навчально-виховного процесу та підвищення кваліфікації вчителів» [29, с. 14]. Турбуючись про навчання учнів грамоті та письму, розширення їхнього загального культурного й освітнього рівня, громадівці багато працювали над створенням шкільних бібліотек, розповсюдженням книг. Як член комітету Петербурзького 
товариства грамотності О. Кониський у своїх зверненнях до урядових установ відстоював ідею національної школи, потребу початкового навчання рідною мовою; розгорнув діяльність із поширення знань серед сільського населення Полтавщини, організував розповсюдження популярної літератури [27, с. 46].

31861 р. О. Кониський став постійним кореспондентом першого українського часопису «Основа», у якому часто виступав під псевдонімом Переходовець. За завданням редакції він їздив по містах і селах України, вивчаючи проблеми народної освіти, шкільництва, а потім свої враження від подорожей друкував у журналі у формі листів, нарисів. Так, у своїх публікаціях «Вісті. 3 Полтави» (1861) [12], «Листи з Полтавщини» (1862) [18], «3 Полтави» (1862) [16], «3 Лубен» (1862) [9, 10], О. Кониський відстоював право українського народу на здобуття освіти рідною мовою. На сторінках «Основи» у 1862 р. він опублікував невелику розвідку «Нанські граматки» [20], в якій він не лише проаналізував 3 погляду методики сучасні йому букварі та граматки, а й обгрунтував своє бачення досконалого підручника для початкового навчання. У рамках широкої програми освіти для народу, яку опублікував М. Костомаров в «Основі» у 1862 р., О. Кониський видав два підручники для початкової школи, а саме: «Українські прописи» (зразки для писання) (Полтава, 1862), «Арифметика або щотниця для українських шкіл» $(1863,1907)$ [1, с. 6]. Підготовлені ним підручники з географії, історії, правознавства не були допущені до друку цензурою.

«Арифметика або щотниця», видана завдяки М. Костомарову, уміщувала практичний матеріал, зрозумілий і близький школяреві: задачі «про косарів, баштани, землю і ії вимірювання, про борошно, хліб, чумаків, які їздили по сіль» тощо. Як учитель-практик автор, розташовуючи навчальний матеріал, дотримувався дидактичних принципів наочності, зв’язку навчання з життям. «Щотницю» Олександр Якович закінчував уже перебуваючи на засланні на Вологодщині, куди потрапив 1863 р. через переслідування представників громадсько-культурного руху.

3 серпня 1861 р. деякі діячі полтавської громади (О. Стронін та О. Кониський) стали членами Петербурзького Комітету Грамотності при III-му Відділі Імператорського Вільного економічного товариства [3, с. 21]. Так, у своєму листі до голови Комітету С. С. Лошкарьова він зазначав: «Желая быть членом Комитета грамотности, имею честь предложить с своей стороны следующие услуги: 
1. Взносить ежегодно по назначению комитета десять руб. сер., считая год с января месяца.

2. Доставлять Комитету через каждые 2 месяца сведения о народных школах тех местностей Херсонской, Полтавской и Черниговской губерний, в которых придётся мне быть.

3. Доставлять сведения о наблюдениях над школами и о средствах к распространению грамотности между населением здешнего края.

4. Принимать все меры к устройству в Полтаве, раза два в год, в пользу комитета концертов и литературных чтений.

5. Приглашать других, преимущественно из сельского населения, в члены, сотрудники или корреспонденты Комитета.

6. Быть постоянно преподавателем в Полтавских воскресных школах (в одной школе я состою уже преподавателем с января сего года).

7. Распространять в народе через продажу и дар издания комитета.

Поэтому покорнейше прошу Комитет грамотности при согласии принять мои посыльные услуги, почтить меня уведомлением, как о согласии, так и о том: а) куда выслать и в какое время мой ежегодный взнос... и б) о ближайших и необходимейших обязанностях члена комитета» [7, арк. 184-185].

Переглядаючи цього листа, бачимо у ньому цілу програму освітньої діяльності полтавських громадівців. Ця програма не була складена випадково. 3 окремих пунктів виступають класові позиції самого автора, представника тих прошарків населення, що сподівалися прислужитися освіті багатьох робітників та селян, вносячи щороку 10 карбованців, влаштовуючи концерти та вистави і поширюючи видання Комітету.

На берегах зазначеного листа О. Я. Кониського олівцем зазначалося, що треба подякувати адресатові та запропонувати йому стати членом «Комітету» [7, арк. 185]. Проте цю резолюцію не виконано, оскільки через деякий час громадський діяч надіслав до Комітету нового листа, де вже висунув гасло національної освіти та пропонував від імені полтавських діячів ряд практичних заходів щодо поширення української народної освіти. У цьому листі автор також вказував на необхідність розповсюдження підручників українською мовою: «Беда в том, что на этом языке нет тех именно книг, которых требует народ ... Кроме того книги продаются слишком дорого» [8, арк. 190].

11 січня 1862 р. Комітет грамотності при Вільному економічному това-ристві на засіданні заслухав подання О. Кониського, де зазначалося: «Населення тутешньої місцевості розмовляє мовою, 
зовсім окремою від великоросійської, а тому з жадобою читає книжки малоруською мовою» [8, арк. 76-76 зв.]. Підтвердженням цього $€$ те, що в «Журнале Комитета» за 1862 р. опубліковано постанову: «...Комитет признал потребность в руководствах на малороссийском языке и в особенности по части естествознания» [7, арк. 192]. За відношеннями та повідомленнями Олександра Яковича на засіданнях згаданої установи неодноразово розглядалися питання розвитку освіти в Наддніпрянській Україні, зокрема «про перебіг грамотності в Харківській губернії», «про незадовільний стан кременчуцьких недільних шкіл» тощо. Основною заслугою О. Я. Кониського у цій справі було те, що Петербурзький Комітет грамотності встановив стосунки з діячами Катеринославської, Київської, Полтавської, Харківської, Херсонської та Чернігівської громад [8, арк. 154].

На почаку 1860-х рр., за свідченням О. Я. Кониського, у Полтаві діяло 7 недільних шкіл. «Почнемо наші вісті про Полтаву 3 того, - писав він, - що найближче лежить біля нашого серця, в чому найбільший вжиток для народу вбачаємо, що робить людей i розумними, і добрими, і правдивими - себто грамотність і школа» [15, с. 321]. Далі автор аналізував статистичні дані цього міста в розрізі потреб освіти. Адже на той час у Полтаві було 27 тисяч жителів і налічувалося 12 навчальних закладів різних типів, у яких навчалося 1557 дітей. Однак, О. Я. Кониський переконаний, що ці школи міські потреби народної освіти не задовольняли. У них навчалися переважно діти заможних людей і панів. «Всі бачили, яка велика потреба народної грамотності у нас перед очима, всі розуміли, що навчання однаковісінько корисне і тим, котрі думають стати суддями і генералами, і тим, котрі свій вік проведуть хто над обручем, хто за чоботом, хто за плугом». Далі автор дякував Богу, що знайшлися добрі люди, які допомогли у народній біді, й була відкрита недільна безкоштовна школа. До неї з першого дня прийшло навчатися 35 учнів, серед яких були як семилітні, так і сорокалітні. Пізніше тут навчалося майже 200 осіб [15, с. 322].

О. Кониський дбав і про створення освіти для дівчат, про це він писав: «Ще з 1858 р. побутувала думка про заснування школи для дівчат. I такі намагання не загинули. 26 серпня 1861 року відкрили Дівоче училище, у якому навчалося 203 дівчини» [22, с. 145-148]. На чолі жіночої гімназії стояла полтавська поміщиця С. Милорадович. Про те, як вона організовувала роботу у жіночій недільній школі, зазначав у своїй кореспонденції «З Полтави» («Основа», 1862) О. Кониський: «3-го сентября одкрита дівоча недільна школа. Хазяйнує у сій школі 
в. п. Милорадовичка, - щиро й працьовито. У школі грошей і книжок доволі, доволі й учениць: записано 150» [16, с. 68-70].

О. Я. Кониський працював учителем у першій чоловічій недільній школі. Навесні 1861 р. він був одним з ініціаторів відкриття другої недільної школи, проте місцева влада стала на заваді цього проекту. Тоді Олександр Якович разом із учнями п'ятих-сьомих класів Полтавської гімназії звернулися за допомогою до управителя дирекції шкіл Полтавської губернії - С. Гейслера [3, с. 10-14], який, звертаючи увагу на велику потребу полтавського населення в освіті, просить дозволу куратора Київського учбового округу відкрити при полтавській гімназії «в виде опыта на один год, бесплатную ежедневную мужскую школу» [7, арк. 103]. У квітні 1861 р. почала діяти суботня школа під керівництвом О. Я. Кониського [3, с. 6]. Таким чином, вже у квітні 1861 р. О. Я. Кониський очолив суботню школу, також утримував щоденну вечірню школу, де сам займався викладацькою діяльністю. Разом з О. І. Строніним Олександр Якович організовував у недільних школах народні читання, які проводилися переважно українською мовою. Щоб селяни краще усвідомили сутність та особливості аграрної реформи 1861 р., він робив спроби перекласти українською «Положення про селян, що вийшли з кріпосної залежності». У березні 1862 р. за ініціативою О. Я. Кониського було відкрито вечірню чоловічу школу, але конкретних даних про її стан немає [8, арк. 102]. Організаційною та навчально-методичною роботою недільних шкіл керувала загальна рада в складі Є. І. Милорадович (голова), діячів полтавської громади - О. І. Строніна (секретар), О. Я. Кониського, Д. П. Пильчикова та місцевих вчителів [3, с. 7].

У недільних школах навчання відбувалося безкоштовно. Тут отримували початкову освіту переважно підлітки та дорослі міщани й селяни, яким не вистачало коштів на навчання. Такі школи працювали у неділю й святкові дні.

Однією з центральних проблем у школах була проблема викладання українською мовою. На сторінках «Основи», після публікацій М. І. Костомаровим низки статей під загальною назвою «Мысли южнорусса», однією з яких була «О преподавании на южнорусском языке», О. Я. Кониський закликав проводити навчання рідною мовою шляхом вибору самих учнів. Цікаві відомості стосовно вибору школярами, якою мовою вони хотіли б навчатися, українською чи російською, подав у своїй праці М. Гніп. Так, діячі полтавської громади В. Лобода, О. Стронін і О. Кониський запровадили опитування: ходили по класах і читали байку I. Крилова та схожу за темати- 
кою байку С. Гребінки, а потім запитували в учнів якою мовою вони хочуть навчатись. Таким чином, за висловом О. Кониського, із 140 опитаних за «гребінчину» мову висловились 123 учні. Однак, зазначимо, що у більшості повітових недільних шкіл навчання проводилися російською мовою. Про це свідчать численні листи до редакції «Основи», а також звіти громадських діячів, які їздили по губернії, вивчаючи стан викладання у повітових школах $[9 ; 10 ; 12 ; 18 ; 21]$.

Крім численних мовних заборон та організації і відкриття шкіл була проблема нестачі україномовних підручників. О. Я. Кониський не тільки поширював серед учнів «Граматку» П. О. Куліша, «Букваря южнорусского» Т. Г. Шевченка та інших, а й сам приступив до складання україномовних підручників. У 1862 р. у Полтаві видано «Українські прописи» О. Кониського [1, с. 8]. Водночас він дбав і про поширення та популяризацію української книги. Оскільки книги українською мовою не могли потрапити на полиці книгарень, поширювачам доводилося продавати їх на базарах та через різних приватних осіб.

Та крім вищезазначених проблем, були ще й проблеми організації навчального процесу: нестача як вчителів, так і учнів. Деякі вчителі не завжди приходили на роботу, часто запізнювались тощо. Щоб запобігти цьому полтавські громадівці (В. В. Стронін та О. Я. Кониський) організовували народні читання у недільних школах губернії, які виявилися досить популярними [26, с. 321]. Народолюбці проводили досить нестандартні, як на той час, уроки. Щоб учням не було нудно на уроках, учителі спочатку читали їм твори Т. Шевченка, Г. Квітки-Основ'яненка, російських класиків - О. Пушкіна, М. Гоголя та ін. Потім викладали історію, географію, природознавство. Лекція обов'язково закінчувалася гумористичним читанням, наприклад, байкою Л. Глібова. Як член Київської міської думи (обраний 1878 р.) Олександр Якович звертався до міністра освіти щодо скасування Емського указу 1876 р., домагався запровадження у школах рідної мови.

У 1882 р. О. Кониський видав український підручник «Граматка або перша читанка задля початку вчення» [1, с. 8]. Адресуючи цю книгу учням, педагог насамперед ставив перед собою завдання ясно, просто й доступно викласти навчальний матеріал, прагнучи максимально полегшити процес його засвоєння. Автор реалізував у підручнику дидактичний принцип зв'язку навчання з життям. О. Кониський популяризував українську освіу на сторінках і галицьких видань. У журналі «Правда» він публікував свої художні твори й наукові розвідки, виступав зі статтями, в яких порушував проблеми 
шкільної освіти й національного виховання («Український націоналізм», 1875; «Потреба морального виховання», 1888; «Народна моральність на Україні», 1892 тощо).

Багато громадських діячів вважали О. Кониського видатним учителем. Так, наприклад, С. Єфремов вважав його своїм духовним батьком, наставником, вчителем. Історик залишив про педагога цікаві спогади, зокрема про його літературно-громадську діяльність у Галичині, у праці «Про дні минулі» [4]. У 1888 р. за сприяння О. Кониського у Львівському університеті було засновано кафедру української історії з українською мовою викладання, яку очолив М. Грушевський.

О. Кониський був одним із тих педагогів, які започаткували процес формування основ української національної школи. На переконання педагога, тільки на грунті національної освіти та демократизації суспільства можливе поліпшення економічного становища народу. У педагогічних працях і підручниках О. Кониського окреслено його принципи побудови системи освіти та виховання в українській школі, яка має бути національною за змістом, формами та інтересами. «Школа повинна не тільки вчити, але й виховувати... вигодувати міцне народолюбство», - наголошував просвітник $[15$, с. 321$]$. Проблеми змісту освіти знайшли своє відображення у багатьох працях О. Кониського.

Статті О. Кониського, присвячені шкільній освіті, дають можливість виокремити предмети, які, на його думку, є пріоритетними для вивчення в школах: українська мова (читання і письмо), математика,географія та історія, Закон Божий. Як вважав педагог, центральне місце в системі навчальних дисциплін національної школи має посідати рідна мова («Наські граматки» (1862), «Вісті. 3 Полтави» (1861), «Потреба історичної освіти» (1888) тощо). Головним джерелом для навчання рідній мові, на думку О. Кониського, слугують кращі вітчизняні твори українських та зарубіжних письменників, усна народна творчість, поезія та проза [1]. Також педагог проаналізував у своїх статтях проблеми, пов'язані з підготовкою вчителів для українських шкіл, підвищенням їхньої кваліфікації, покращенням соціального і правового становища, матеріально-побутових умов життя і праці («Потреба реформи в освіті жіноцтва» (1888), «Вісті. 3 Харкова» (1892).

Провідною ідеєю в педагогічній системі О. Кониського було національне виховання, яке мало базуватись на природі дитини, враховуючи іiі індивідуальні й національні риси та якості, забезпечувати гармонійну єдність розвитку особистості з фізичним, моральним і духовним розвитком нації. 
Спадщина О. Кониського обіймає чільне місце в історії вітчизняної педагогічної думки. Він є автором багатьох оригінальних робіт з історії освіти, історії культури, літературознавства, дидактики, розвитку освіти і шкільництва в Україні, в яких проблема освіти $\epsilon$ предметом постійної дослідницької уваги. У численних своїх працях педагог ставить питання сімейного, морального виховання; реформування змісту жіночої освіти, в основі якої - навчання рідною мовою; вищої освіти жіноцтва. Ідеї педагога були переглянуті та розвинуті згодом у працях нової генерації української інтелігенції, зокрема Б. Грінченка, М. Грушевського, С. Русової, Я. Чепіги, I. Ющишина та інших. Погляди О. Кониського на проблеми розвитку національної школи не втратили своєї актуальності й нині та потребують подальшого вивчення і творчого використання у процесі розбудови сучасної національної школи і освіти.

\section{БІБЛІОГРАФІЧНІ ПОСИЛАННЯ}

1. Бслан Г. В. Педагогічні погляди і просвітницька діяльність Олександра Кониського: дис... канд. пед. наук: 13.00.01 / Г. В. Бєлан // Інститут педагогіки АПН України. - Київ, 2004.

2. Возняк М. Листування Панька Куліша з О. Кониським / М. Возняк // Нова Україна. - 1923. - № 10-11. - С. 139-162.

3. Гніп М. Громадський рух 1860 рр. Кн. Перша: Полтавська громада / М. Гніп. - Харків: Держ. Вид-во України, 1930. - 236 с.

4. Єфремов С. Про дні минулі: [спогади] / С. Єфремов // Молода нація. - Київ, 2003. - C. 126-169.

5. Житель Полтави. Изъ Полтавы (Полтавская женская гимназия) // Основа. 1861. - № 1. - C. 323-328.

6. Жураковський Г. Є. Из истории Просвещения в дореволюционной России / Г. Жураковский. - М. : Мысль, 1978. - С. 82-133.

7. Жураковський $\boldsymbol{\Gamma}$. $\mathbf{\epsilon}$. Очерки статьи и исследования по истории просветительной деятельности Полтавской громады 60-х гг. ХІХ ст. - ДАПО. - Ф. 8831, оп. 3, спр. 3, арк. 1-238.

8. Жураковський Г. Є. Статьи и исследования по истории украинского просветительного движения времен возникновения Старой Киевской громады (1859-1863) / Г. Є. Жураковський. - ДАПО.- Ф. 8831, оп. 3, спр. 3, арк. 1-164.

9. Изъ Лубенъ (Полтавской губ.) // Основа. - 1861. - май. - С. 74-76.

10. Изъ Лубень (Полтавской губ.) // Основа. - 1861. - октябрь. - С. 148-150.

11. Кониський О. Автобіографія / О. Кониський. - ІЛ НАНУ ВРФТ. - Ф. 77, оп. 1, спр. 1604, арк. 86-90.

12. Кониський О. Я. Вісті з Полтави / О. Я. Кониський // Слово. - 1862. Ч. 32. - С. 48.

13. Кониський О. Я. Воспоминания о Полтаве в начале 60 -х годов / О. Я. Кониський // Днепровская Молва. - 1900. - № 3. - С. 8.

14. Кониський О. (Перебендя). Довідка про заборонені в Росії українські книжки / О. Кониський. - ІЛ НАНУ ВРФТ. - Ф. 3, оп. 1, спр. 1608, арк. 531-532. 
15. Кониський О. Я. 3 Полтави / О. Я. Кониський // Основа. - 1861. - № 1. C. 319-328.

16. Кониський О. Я. 3 Полтави / О. Я. Кониський // Основа. - 1862. - № 2. - С. 68-70. 17. Кониський О. Я. Із Полтави / О. Я. Кониський // Основа. - 1861. - № 5. - С. 68-71. 18. Кониський О. Я. Листи з Полтавщини / О. Я. Кониський // Слово. - 1862. - Ч. $43 .-$ С. 68.

19. Кониський О. Народна моральність на Україні / О. Я. Кониський // Правда. - 1892. - № 3. - С. 146-152.

20. Кониський О. Я. Наські граматки / О. Я. Кониський // Основа. - 1862. № 1. - C. 64-82.

21. Кониський О. Я. Огляд стану освіти на Україні / О. Я. Кониський. - ІЛ НАНУ ВРФТ. - Ф. 77, оп. 1, спр. 27, арк.1-3 зв.

22. Кониський О. Я. Полтавская женская гимназия / О. Я. Кониський // Основа. - 1861. - № 1. - С. 145-148.

23. Ніс С. Листи до О. Я. Кониського (1861 р.) / С. Нic. - ІЛ НАНУ ВРФТ. Ф. 77, оп. 1, спр. 125, арк. 72-76.

24. Переходовець О. [Кониський О.]. 3 Млинів / О. Я. Кониський // Основа. 1862. - Май. - С. 19-22.

25. Переходовець [Кониський О.]. 3 Старих Санжар / О. Я. Кониський // Основа. -1862 . - № 5. - С. 11-16.

26. Переходовець О. (О. Кониський). Вісті / О. Переходовець // Основа. 1861. - № 1. - C. 319-322.

27. Побірченко Н. С. Педагогічна і просвітницька діяльність українських Громад у другій половині XIX - на початку XX ст.: у 2 кн. - Кн. 1: Київська Громада / Н. С. Побірченко. - Київ: Наук. світ, 2000.

28. Про Конотипъ // Основа. - 1861 - октябрь. - С. 7-9.

29. Рогова П. І. Педагогічні бібліотеки України (друга половина XIX 20-ті роки XX ст.): [монографія] / П. І. Рогова. - Київ: Четверта хвиля, 2009. - 270 с. 30. Світленко C. I. Світ модерної України кінця XVIII - початку XX століття: [зб. наук. праць] / С. І. Світленко. - Дніпропетровськ: Герда, 2007. - 460 с.

31. Стронін О. І. Лист до О. Кониського від 18. 03. 1862 р. / О. І. Стронін. ДАПО. -Ф. 417, оп. 1, спр. 54, арк. 1-2 зв.

Надійила до редкол.: 12. 03. 2018 